CONFLICTING COMMITMENTS 


\section{CONFLICTING COMMITMENTS}

The Politics of Enforcing Immigrant Worker Rights in San Jose and Houston

\section{SHANNON GLEESON}




\section{Copyright $(\odot 2012$ by Cornell University}

All rights reserved. Except for brief quotations in a review, this book, or parts thereof, must not be reproduced in any form without permission in writing from the publisher. For information, address Cornell University Press, Sage House, 512 East State Street, Ithaca, New York 14850.

First published 2012 by Cornell University Press

First printing, Cornell Paperbacks, 2012

Printed in the United States of America

\section{Library of Congress Cataloging-in-Publication Data}

\section{Gleeson, Shannon, 1980-}

Conflicting commitments : the politics of enforcing immigrant worker rights in San Jose and Houston / Shannon Gleeson.

$$
\text { p. } \mathrm{cm} \text {. }
$$

Includes bibliographical references and index.

ISBN 978-0-8014-5121-8 (cloth : alk. paper)

ISBN 978-0-8014-7814-7 (pbk.: alk. paper)

1. Foreign workers-California-San Jose. 2. Foreign workersTexas-Houston. 3. Foreign workers-Legal status, laws, etc.California-San Jose. 4. Foreign workers-Legal status, laws, etc.Texas-Houston. 5. Employee rights-California-San Jose.

6. Employee rights-Texas-Houston. 7. Illegal aliens-CaliforniaSan Jose. 8. Illegal aliens-Texas-Houston. I. Title.

HD8081.A5G54 2013

331.6'2097641411—dc23 2012024641

Cornell University Press strives to use environmentally responsible suppliers and materials to the fullest extent possible in the publishing of its books. Such materials include vegetable-based, low-VOC inks and acid-free papers that are recycled, totally chlorine-free, or partly composed of nonwood fibers. For further information, visit our website at www. cornellpress.cornell.edu.
Cloth printing
$\begin{array}{lllllllllll}10 & 0 & 9 & 8 & 7 & 6 & 5 & 4 & 3 & 2 & 1\end{array}$
Paperback printing
$\begin{array}{lllllllllll}1 & 0 & 9 & 8 & 7 & 6 & 5 & 4 & 3 & 2 & \end{array}$ 
Para mi mama y abuelita, Maristela Robinson y Marta Aldana Cruz

Debo todo mi exito a sus sacrificios

To my mom and grandma, Maristela Robinson and Marta Aldana Cruz I owe all my success to your sacrifices 


\section{CONTENTS}

Acknowledgments $\quad$ ix

List of Abbreviations xiii

Introduction: Immigrant Labor in the United States 1

1. Work in Postindustrial America $\quad 30$

2. Implementing the Legal Rights of Undocumented Workers $\quad 64$

3. Place Matters: How Local Governments

Enforce Immigrant Worker Rights $\quad 89$

4. Beyond Government: How Civil Society Serves,

Organizes, and Advocates for Immigrant Workers 118

5. Advocating across Borders: Consular Strategies for Protecting Mexican Immigrant Workers 
viii

Conclusion: Making Rights Real for Immigrant Workers

Notes

References

Index 


\section{ACKNOWLEDGMENTS}

After years of researching and writing this book, the process of accounting for all the people who have helped me reach this point seems the most daunting. I will do my best.

The seeds of this book were planted over a decade ago in O'Connor Hall at Santa Clara University. My mentors at SCU, especially Marilyn Fernandez, Chuck Powers, and Laura Nichols, sparked my sociological imagination and have supported me every step of the way since. My committee members in the Departments of Sociology and Demography at UC Berkeley helped lay the foundation for this research. I offer thanks especially to Irene Bloemraad, Sam Lucas, Mike Hout, Kim Voss, Michael Burawoy, Ron Lee, and Margaret Weir. Each fueled my intellectual curiosity in ways that weren't always immediately apparent, but which always came full circle. Special thanks to the Interdisciplinary Immigration Workshop, the Migration Working Group at the Center for Latino Policy Research, Gene Hammel, Lauren Edelman's law and society workshop, and Claude Fischer's sociology writing workshop. Countless colloquia at 
the Center for Law and Society, the Survey Research Center, the Center for Latin American Studies, the Institute for Research on Labor and Employment, and the Institute of Governmental Studies created fertile ground for the development of this book as well. I owe a debt of gratitude to all the Berkeley staff who worked behind the scenes to make these events a success. Thanks go especially to Carl Mason and Carl Boe in the Department of Demography, Jon Stiles at the SRC, and Terry Huwe at IRLE for all the technical assistance you provided over the years.

So many other colleagues and friends at Berkeley read early drafts, tore them apart, and helped me build them back up. Thanks in particular to Ming Hsu Chen, Roberto G. Gonzales, Rebecca Hamlin, Damon Mayrl, Helen Marrow, Ben Moodie, Osagie Obasogie, Marcel Paret, Karthick Ramakrishnan, Aliya Saperstein, Rachel Sullivan, Laurel Westbrook, and Phil Wolgin for offering your candid thoughts and never-ending encouragement. This book could not have been possible without two amazing scholars: Els de Graauw and Amada Armenta read more versions than any writing partner should ever be forced to, had the patience to walk me through difficult paragraphs, and always stepped up to the plate for my last-minute requests.

My colleagues at UC Santa Cruz have been beyond supportive. Jill Esteras and Alessandra Alvares welcomed me and instantly made me feel at home. The faculty in the Latin American and Latino Studies Department, the Chicano/Latino Research Center, and the Center for Labor Studies created an intellectual community where I could thrive. Gabriela Arredondo, John Borrego, Jonathan Fox, Susanne Jonas, Steve McKay, Hector Perla, Cecilia Rivas, and Pat Zavella in particular offered constructive feedback and thought-provoking discussion. Sandra Alvarez, Eric Arce, Jimmy Chiu, Susana Duro, Joe Garcia, Brian Jimenez, Claudia Medina, Anel Morales, Catherine Lagayan, Mariela Rodriguez, and Angelica Rodriguez all provided awesome research assistance. Ruth Homrighaus provided impeccable editing skills, and Paula Durbin-Westby masterfully created this book's index.

In the brave new world of research and publishing, I was privileged to be supported by several funders, including the National Science Foundation, the Ford Foundation, the UC Labor Employment and Research Fund, the UC Center for New Racial Studies, UC MEXUS, the UCSC Chicano/Latino Research Center, and the UCSC Committee on Research. My year as a Ford Postdoctoral Fellow at Santa Clara University and the 
Katharine and George Alexander Community Law Center was invaluable for bringing this book to fruition. The generosity of the Hellman Family Fund also supported publication expenses. I am grateful also for the patience of Fran Benson, Kitty Liu, Susan Specter, and the rest of the editorial staff at Cornell University Press, and to the anonymous reviewers who provided me with their vital suggestions.

Parts of this book, in revised form, were previously published in "Organizing for Latino Immigrant Rights in Two U.S. Cities: The Case of San Jose and Houston," in Civic Hopes and Political Realities: Immigrants, Community Organizations and Political Engagement, ed. S. Karthick Ramakrishnan and Irene Bloemraad (New York: Russell Sage Foundation Press, 2008), 107-33, and in "Labor Rights for All? The Role of Undocumented Immigrant Status for Worker Claims-Making," Law and Social Inquiry 35, no. 3 (2010): 561-602.

My dear friends have been an immense source of support. Heartfelt thanks go to Angelina Bouchard, Rhonda Campbell, Shelly Grabe, Darren Noy, Cheryl Holzmeyer, Milton Magafia, Cristina Mora Torres, Chris Sullivan, and Leslie Wang for the many hours on the phone, on the couch, and on the trails. My family has seen me through this process, and been there every step of the way. Above all, my mother's love and support have always been unfailing, and it is she who taught me the dignity of work, and the importance of justice and equality for everyone. It is her example that I have strived to follow my entire life. My little brother Danny has kept me out of the dark ages of pop culture, given me unconditional love, and made me so proud. To Grandma, Abuelita, Tia, Dad, Arthur, Aunt Steph, Uncle Michael, Tom, Carol, Poppy, Bud, Erin, Estela, Ms. Turner, and all my other aunts, uncles, and cousins - thank you for all your support and for always keeping a smile on my face. Chahta and Hya have kept me company for hours on end of writing, and snapped me back to reality when there was nothing more important than dinner and playing ball. Catch-A-Bear, I miss you. And most important, Gabriel Carraher has stood by me through it all, somehow knowing exactly when to let me work, when to feed me, and when to force me to go to bed. Thank you for all your love, support, and patience. I can't wait to get back to the beach with you.

I am forever indebted to the dozens of government bureaucrats, nonprofit staff, and consular representatives who agreed to speak with me, despite clearly more pressing matters. Thank you all for telling me your story 
and helping me understand the importance of the work you do. Final and deepest thanks go to the workers who motivate this book. For all the immigrants who continue to cross the border every day to make a better life for themselves and their families, and whose struggle for justice continues, this book is for you. 


\section{ABBREVIATIONS}

ABA American Bar Association

ACORN Association of Community Organizations for Reform Now

AFL-CIO American Federation of Labor and Congress of Industrial Organizations

AIR Americans for Immigration Reform

AJC American Jewish Committee

BLS Bureau of Labor Statistics

BPUSA Building Partnerships USA

Cal/OSHA California Occupational Safety and Health Administration

CDLE Colorado Department of Labor and Employment CIPC California Immigrant Policy Center

CJD Casa Juan Diego

CRA Civil Rights Act

CTW Change to Win 
DFEH Department of Fair Employment and Housing

DHS Department of Homeland Security

DLSE Division of Labor Standards Enforcement

DOL Department of Labor

DOL-WHD Department of Labor-Wage and Hour Division

DOS Department of State

DWU Domestic Workers United

EBASE East Bay Alliance for a Sustainable Economy

EEOC Equal Employment Opportunity Commission

FLSA Fair Labor Standards Act

GAO Government Accountability Office

HCIR Houston Coalition for Immigration Reform

HERE Hotel Employees and Restaurant Employees

International Union

HIW J Houston Interfaith Worker Justice

HIWS Houston Initiative on Worker Safety

HPD Houston Police Department

HRW Human Rights Watch

ICE Immigration and Customs Enforcement

IME Instituto de los Mexicanos en el Exterior

IN A Immigration and Nationality Act of 1952

(McCarran-Walter Act)

INCITE! INCITE! Women of Color against Violence

IOM

International Organization for Migration

IRIS

Immigrant Relations and Integration Services

IWFRC Immigrant Workers Freedom Ride Coalition

IWJ Interfaith Worker Justice

JEWP

Justice and Equality in the Workplace Program

KGACLC Katharine and George Alexander Community

Law Center

LCCR The Lawyers' Committee for Civil Rights Under Law

LIUNA Laborers' International Union of North America

LSEA labor standards enforcement agency

LSLA Lone Star Legal Aid

MACIRA Mayor's Advisory Committee on Immigrant and

Refugee Affairs 
MOIR A City of Houston Mayor's Office of Immigrant and Refugee Affairs

MPI Migration Policy Institute

MTA-ABAG Metropolitan Transportation Commission and Association of Bay Area Governments

NCOSH National Council for Occupational Safety and Health

NELP National Employment Law Project

NILC National Immigration Law Center

NLRB National Labor Relations Board

NRA National Restaurant Association

NRTWO National Right to Work Organization

OECD Organisation for Economic Co-operation and Development

OEHHA Office of Environmental Health Hazard

Assessment

OMB Office of Management and Budget

OSHA Occupational Safety and Health

Administration/Agency

PACT People Acting in Community Together

PHC Pew Hispanic Center

ROC-NY Restaurant Opportunities Center of New York

SBLC

SCC

South Bay AFL-CIO Labor Council

SCC-OHR Santa Clara County Office of Human Relations

SCOPE

SEIU

Strategic Concepts in Organizing and

Policy Education

SIREN

SRE

Service Employees International Union

SVAIR Silicon Valley Alliance for Immigration Reform

SVTC Silicon Valley Toxics Coalition

TMO The Metropolitan Organization

TWC Texas Workforce Commission

TX-SIP Texans for Sensible Immigration Policy

UFCW United Food and Commercial Workers 
UNITE HERE! Union of Needletrades, Industrial, and Textile Employees and the Hotel Employees and Restaurant Employees International Union

WCRI Workers Compensation Research Institute

WHIS ARD Wage and Hour Investigative Support and Reporting Database

WPUSA Working Partnerships USA

YWU Young Workers United 


\section{INTRODUCTION}

\section{Immigrant Labor in the United States}

A hundred years ago, 146 young immigrant women died in one of the largest industrial accidents in U.S. history. Unable to escape the fire at the Triangle Shirtwaist Factory in Manhattan because locked doors sealed them in the building, the young women fell victim to an employer who offered them the "low wages, excessively long hours, and unsanitary and dangerous working conditions" that had become endemic to the industry as a whole (Kheel Center 2011). The exploitation of the mostly Jewish garment workers at the Triangle Shirtwaist Factory has become a touchstone in U.S. labor history. This incident kicked off an extensive labor organizing campaign that fought to institutionalize protections for all low-wage workers, including collective bargaining rights (won in the 1935 National Labor Relations Act), the minimum wage and overtime provisions (the 1938 Fair Labor Standards Act), protections against racial discrimination (the 1964 Civil Rights Act), and industrial health and safety standards (the 1970 Occupational Safety and Health Act), among others. 
In today's de-unionized, postindustrial economy, these protections remain vital for workers. In this book, I examine how these rights are enforced for the growing population of low-wage immigrant-and particularly undocumented-workers. Immigrant workers-not unlike those who perished at Triangle-labor in nearly every low-wage industry across the United States. We interact daily with industries built on cheap immigrant labor. Each morning many of us don designer clothing likely made by an immigrant garment worker who recoups only a fraction of the profit (DOL 2004a), pass construction sites teeming with injured and underpaid immigrant laborers (Valenzuela et al. 2006), and eat food picked or prepared by immigrant women subjected to rampant sexual harassment (Castaneda and Zavella 2003). An estimated 8 million of the 35-millionstrong immigrant workforce are undocumented and considered among the most vulnerable and underpaid (Passel and Cohn 2009; BLS 2010). Their ongoing exploitation has been the focus of much scholarly research and journalistic reporting, such as Stephen Greenhouse's 2005 expose of work conditions in the immigrant-dense Brooklyn neighborhood of Bushwick, a short train ride away from the old Triangle Factory (Greenhouse 2005). Recent one-hundred-year-anniversary commemorations of the tragedy at Triangle remind us that the unpaid wages, dangerous workplaces, and outright discrimination experienced by workers in 1911 are alive and well for workers today. Hourly wages that are almost $\$ 4$ less than the federal minimum, language discrimination, and the indiscriminate firing of pregnant women are all par for the course in Bushwick and nearly every city in the nation.

Unlike the laborers of one hundred years ago, immigrant workers today have access to a range of formal protections. In theory even undocumented workers enjoy a modicum of labor rights, despite ongoing legal challenges to these rights. Though employers are prohibited from hiring undocumented workers, when they do so they are compelled to pay those workers at least the minimum wage and compensate them for any overtime they accrue. They must adhere to antidiscrimination standards and are expected to implement appropriate health and safety protections for all their employees. These rights reflect no arbitrary benevolence, but rather the acknowledgment by labor standards enforcement agents and other worker advocates that the protection of "even [undocumented] workers, is important to prevent the exploitation of any employees, legal or not, and to 
discourage employers from hiring illegal immigrants for cut-rate wages" (Greenhouse 2005).

Even as formal protections have proliferated over the years, their implementation is not a given, particularly for vulnerable populations like undocumented workers. As union membership has declined, workplace rights have become even more important. Nonetheless, ensuring that worker rights exist is only half the battle: getting workers to make claims on those rights, and getting responsible agencies to follow up on those claims, is the other half. Many of the immigrant workers in Bushwick interviewed by Greenhouse knew little of their rights under the law, while others were surprisingly familiar with them but terrified to speak out due to fear of deportation or job loss. A few had actually complained but were ultimately distrustful of the New York Labor Department. For all these workers, the formal existence of rights had little effect on the constant violations they experienced. Thus, immigrants' labor rights must be activated in order to be useful; and while some individual workers can muster the resources and legal consciousness to activate them on their own, most require the assistance of a trusted-and creative-advocate to make these rights real. For those who can afford it, a private lawyer can be an important advocate. Those who can't often turn to a network of community organizations for help. This book examines the strategies deployed by a wide variety of stakeholders who intervene in the enforcement of immigrant workers' rights.

One approach such intermediaries take is simply to help aggrieved workers file claims. Lawyers reach out to workers in order to funnel them to the appropriate bureaucratic apparatus, which might help the workers recoup their lost wages, issue discrimination penalties, or provide other compensation in the wake of injury. In addition to this direct "lawyering" approach, as Gordon (2007) dubs it, labor advocates engage in long-term worker organizing, sometimes with the aim of formal unionization (Fine 2006). Advocates may also focus on advancing policy reform, such as living wage ordinances, or promoting the implementation of existing policies, such as wage theft prevention policies, which have proliferated (Luce 2004; Huq et al. 2006; Bernhardt 2010).

This book examines how immigrant workers' rights are enforced in practice, how claims are channeled, and why and how advocates take on particular battles. In the chapters that follow, I draw on an in-depth 
comparative case study of two immigrant-receiving destinations-San Jose, California, and Houston, Texas-to examine the dynamics of enforcing immigrant worker rights. I consider how certain solutions become commonly understood as appropriate responses to a given issue that affects immigrant laborers, and which actors take on responsibility for the advancement of particular worker problems. For example, why does a construction worker who has been cheated of a week's pay in San Jose get funneled to a local legal aid clinic and eventually a state agency to file a formal claim, while his counterpart working in one of Houston's sprawling track developments will struggle to find any lawyer willing to serve him and will perhaps never set foot in a government office to file a claim? Why do the San Jose police have little to offer this worker, while in Houston any police officer is required to make a theft-of-service report when asked? How is it that if this nonunionized worker were to call the South Bay AFL-CIO Labor Council in San Jose, he would be advised to call the California Department of Labor Standards Enforcement or seek out a local legal aid clinic, while in Houston the Harris County AFL-CIO Council would be more likely to encourage him to pay a visit to city hall, the federal building, or perhaps even a worker center to help organize a direct action, depending on his situation? And how do we understand the vastly different support immigrant workers will find from their consulates in these two cities?

The goal of this book is to help answer these questions and expand our understanding of how immigrant worker rights are enforced and advanced. I situate the rights of immigrant workers in the space between both labor standards enforcement and immigration control, two conflicting jurisdictions whose implementation can vary widely, depending on their local political context. I then look beyond government bureaucrats to understand how enforcement strategies are influenced by local intermediaries who may have diverse interests in the advancement of immigrant worker rights. These include local elected officials, who can either intensify or mitigate the surveillance of undocumented immigrants and promote or stymie the interests of workers; civil society actors, who have direct knowledge of and access to immigrant workers, and who work in diverse ways to advance their rights; and consular institutions, whose unique combination of political legitimacy, institutionalized resources, and 
unfettered support for their emigrant population creates a unique pathway for rights enforcement.

\section{Making Rights Real}

This book examines how actors on the ground promote the rights of immigrant workers and do the work Epp (2010) refers to as "making rights real." Rather than view rights as self-propelled imperatives rooted solely in the law, this analysis highlights the complexity of the enforcement process and the variety of actors implicated in struggles for immigrant workers' rights. Legal scholars have focused at length on the role of the courts (Rosenberg 1991; McCann 1994; Epp 1998), how social movements advocate for particular policy interests (Minkoff 1995; Andersen 2006), the ways individuals develop legal consciousness (Merry 1988, 1990), and the individual and institutional barriers they face to claims-making (Felstiner, Abel, and Sarat 1980; Albiston 2005). In most conceptions of "rights in action," laws are created by political actors influenced by competing interest groups, such as parties and social movements. These policies then often face a series of judicial challenges in which they are subject to various interpretations of the Constitution and legal precedent. The resulting statutes are filtered through the internal regulations of the bureaucracies charged with enforcing them, and those organizational cultures shape the individual behavior of front-line bureaucrats (Lipsky 1980; Mashaw 1985; Brehm and Gates 1999).

Three elements are often missing from this analysis. First, while the discretionary role of bureaucrats has been well documented, the strategies bureaucracies adopt for carrying out their mandates are often not uniform across different contexts. Federal agencies can have dozens of field offices spread across the country, each with distinct challenges and resources at its disposal. In the arena of workplace rights, for example, the federal Equal Employment Opportunity Commission has over fifty offices. The Department of Labor's Wage and Hour Division alone has nearly ninety. In each of these places, federal law must coexist with state and local policies. Even in a context of federalism, where federal law trumps state legislation, the efforts of states and cities can be neutral, helpful, or can pose a significant 
hindrance to the implementation of federal policy. Popular examples of policy arenas in which federalism creates conflict include drug policy, gay marriage, and, increasingly, immigrant rights. The significance of overlapping jurisdictions is not simply bureaucratic: overlapping jurisdictions can also influence how policy goals are implemented. If resources and political will are uneven, the more powerful agency may take the lead. Where there are few resources in place to reach out to claimants, bureaucracies have to get creative with their resource allocation and outreach strategies.

A second piece often missing from the puzzle of rights enforcement is the constellation of organizations outside the bureaucracy that can affect the process. While jurisdictional boundaries are often tightly drawn to define the scope of agencies' activities, the actual process of enforcement frequently lures in additional interested groups. Elected officials can influence how resources are allocated to enforcement bureaucracies and can then pressure them to be used in particular ways. The mayor of a city, for example, may rally for state and federal resources to assist his community, as Ray Nagin famously did for New Orleans in the wake of Hurricane Katrina. City councils and boards of supervisors, often compelled by their constituents, may also decide to invest in certain initiatives that seem insufficiently covered by the responsible bureaucracies at the state and federal level. Social movements not only advocate for particular laws but can also be just as vigilant regarding their implementation. Other civil society groups also make demands on how enforcement resources should be deployed, and some even function as intermediaries in the effort to reach out to potential claimants.

Last, rights do not exist in a vacuum, and policies often clash. These conflicts can become manifest between different levels of government, but the federal government is certainly not itself a unitary actor (Evans, Rueschemeyer, and Skocpol 1985). This is a result not only of a complicated electorate that yields inconsistent popular support but also of the competing demands of nationhood. Laws are formulated to maintain order and protect those who lack power in the social structure. The goals of law enforcement agencies frequently clash with the goals of agencies designed to protect civil rights. The nature of this struggle may vary substantially across contexts, with public support for one agency's goals potentially dwarfing support for that of the other. One of the clearest examples of this contradiction, and the focus of this book, is the simultaneous efforts to 
deter and deport the estimated 5 percent of workers who are unauthorized on the one hand and to protect them from workplace abuse on the other. To this end, the following pages will focus on the institutional dynamics of enforcing the rights of immigrant workers.

\section{Protecting Those Who Work in the Shadows}

As the total undocumented population has grown from a mere 3-6 million in the period prior to the 1986 Immigration Reform and Control Act (Bean, Telles, and Lowell 1987) to close to 12 million by 2009, the fate of the 8 million workers among them has become an increasing topic of concern (Passel and Cohn 2009). Though undocumented workers constitute only 5 percent of all civilian laborers, it is estimated that approximately a quarter of dry wall workers, dishwashers, maids and housekeepers, meat and poultry workers, and roofers are undocumented, as are nearly 70 percent of farmworkers (Greenhouse 2008, 226; Passel and Cohn 2009). Many of the industries where undocumented workers are concentrated are almost completely nonunionized. A mere 1.6 percent of all restaurant and food service workers, 2.2 percent of crop production workers, and 1.1 percent of car washers were union members in 2008 (Hirsch and Macpherson). Union protections are also virtually nonexistent in informal sectors such as day labor and domestic work, where undocumented workers are also common. For these and other nonunionized workers, federal, state, and local labor laws are the sole protection against employer abuse. Immigration status has been deemed irrelevant to a worker's ability to file a grievance against his or her abusive employer. ${ }^{1}$ Failure to provide these protections, most argue, accelerates the race to the bottom for workplace standards. ${ }^{2}$

Yet those attempting to protect the rights of undocumented workers face a legal conundrum. Though these rights exist, undocumented immigrants are barred from legally working by employer sanction provisions instituted through the 1986 Immigration Reform and Control Act, which for the first time interpreted hiring undocumented workers as illegal and punishable by fines. ${ }^{3}$ Employer sanctions were designed to deter employers from hiring unauthorized workers, and proponents assumed they would reduce the demand for migrants seeking work. The net effect of the law as a deterrent to migration flows is negligible, but its chilling 
effect on undocumented workers has been well documented (Wishnie 2007; Golash-Boza 2009). Rather than keep undocumented migrants out, employer sanctions make them more vulnerable to employer abuse by creating a perverse set of incentives for employers to exploit them and by deterring undocumented workers from speaking out against this abuse (Wishnie 2007; Bacon and Hing 2010).

One of the most far-reaching responses to the conflict between immigration enforcement and noncitizen rights was the 2002 U.S. Supreme Court Case Hojfman Plastic Compounds, Inc. v. National Labor Relations Board. In a 5-4 decision, Hojfman ultimately banned the provision of back pay to undocumented workers who have been unjustly fired for organizing a union and effectively removed the National Labor Relations Board's ability to require reinstatement in such cases (Berman 2004). This decision has had ripple effects for efforts to protect undocumented workers from exploitation. The majority opinion, penned by then chief justice Rehnquist, argued that providing full rights to undocumented workers would ultimately serve as a magnet for future flows and encourage their employment. The minority opinion, written by Justice Breyer, on the other hand, argued that to deny rights to undocumented workers "lowers the cost to the employer of an initial labor law violation [and] increases the employer's incentive to find and to hire illegal-alien employees." ${ }^{4}$

Since Hojfman, the protections of back pay and reinstatement have not been available to undocumented workers, but other formal protections remain in place. These include the ability for labor standards enforcement agencies to collect unpaid wages for a claimant's hours worked and to protect workers against arbitrary discrimination and harassment prohibited under civil rights legislation, to enforce basic health and safety standards, and in some cases even to require compensation and medical treatment in the wake of an injury. In fact, one of the first things many labor standards enforcement agencies did following Hojfman was to issue public statements that reiterated their stance toward undocumented workers. The Department of Labor, for example, emphasized that the Court's decision in Hojfman "does not mean that undocumented workers do not have rights under other U.S. labor laws" and reassured the public that the agency would "continue to provide core labor protections for vulnerable workers ... without regard to whether an employee is documented or undocumented" (DOL 2008). Similarly, the Equal Employment Opportunity 
Commission issued a press release avowing that the Hoffman decision "does not affect the government's ability to root out discrimination against undocumented workers," and it reiterated that "enforcing the law to protect vulnerable workers, particularly low income and immigrant workers, remains a priority for EEOC" (EEOC 2002b). Despite these assurances, a wide gulf persists between the rights afforded to undocumented workers on the books and those that ultimately materialize in practice.

One could argue that the existence of workplace rights for the undocumented defies classic understandings of citizenship that presuppose political membership as a prerequisite for access to social citizenship (Marshall 1950). Yet the simultaneous efforts to identify and deport undocumented immigrants while also attempting to protect them from exploitation reflect what Bosniak (2006) refers to as the "two faces of citizenship" in modern liberal democracies. That is, despite the impulse to police the physical and political borders of membership, the United States is also compelled to offer some modicum of rights and equality even to noncitizens. The need to enforce immigration laws and the need to enforce labor standards are dual aspects of maintaining law and order. Ultimately, however, the paradoxical existence of undocumented workers affects not only individual claims-making behavior but also how bureaucracies collaborate (or stay out of each other's way) and how advocates strategize in the complicated dance of enforcement.

On the bureaucratic end, labor standards enforcement agencies have deployed resources to reach out to undocumented workers and reaffirm their interest in protecting undocumented workers' rights. This challenge is closely tied to the dismal state of labor standards enforcement more generally. Despite a 900 percent increase in the size of the American workforce since 1941, the Department of Labor's Wage and Hour Division relies on 50 percent fewer investigators today than it did then (Bobo 2008, 116). The Occupational Safety and Health Administration has also been criticized for being ineffective at reducing injury rates and for failing to adequately regulate several hazardous chemicals that pose risks to workers (Michaels 2007). These inadequacies are intensified by the fact that private-sector union coverage today is at its lowest level since 1973, the first year for which reliable data is available (Hirsch and Macpherson).

President Obama has promised to reverse this trend, pledging to stop globalization's race to the bottom for U.S. workers by strengthening 
collective bargaining provisions, promoting health and safety laws, and ensuring that "dollars earned are dollars paid" (Talbott 2008; OMB 2010). The 2009 confirmation of Hilda Solis to head the Department of Labor was seen as a hopeful sign of positive changes to come in the enforcement of worker rights. Solis, the daughter of Latino immigrant parents and someone with deep connections to organized labor, declared she would confront those employers who intend to "cut corners and disregard safety in the workplace" or seek to "to deny workers a voice" (Solis 2010). Within her first year in office, Solis launched a campaign to tackle the long-ignored issue of wage theft and deployed the "We Can Help" / "Podemos Ayudar" campaign, which ran public service announcements explaining how workers could seek out help and emphasizing that all workers would be treated equally, regardless of immigration status (DOL 2010c). Solis has coupled her commitment to immigrant labor with outspoken calls for comprehensive immigration reform (DOL 2010a). In the interim, the Department of Labor has pushed for clear commitments from Immigration Customs Enforcement not to interfere in DOL investigations. ${ }^{5}$

The devastating effect of immigration enforcement on labor standards enforcement has been demonstrated by several high-profile incidents over the years, such as the May 2008 raid in the small northeastern Iowa town of Postville. Following a daylong Department of Homeland Security operation at the nation's largest kosher slaughterhouse, a major organizing campaign and workplace violation investigation was disrupted, and nearly four hundred mostly Mexican and Guatemalan workers were deported. ${ }^{6}$ These workers' access to formal workplace rights diminished nearly to the vanishing point in the face of their impending incarceration and eventual deportation. For months, the United Food and Commercial Workers had been waging an organizing campaign while the Iowa labor commissioner investigated alleged workplace violations at the plant. Violations ranged from run-of-the-mill wage and hour infractions to egregious abuses of power, such as the beating of a worker whose eyes were first duct-taped by a supervisor wielding a meat hook (Hsu 2008; Landon 2008). What Postville reveals is that despite the well-intended efforts of labor standards enforcement, such as those launched under the leadership of Obama and Solis, the overarching threat of detention and removal permeates all aspects of the undocumented work experience. The accessibility of workers' formal rights on the books must be understood within this context. 
The power of immigration enforcement reaches further than just the workers who are unfortunate enough to be caught in a raid. The majority of undocumented immigrants working in the United States are never detained or deported. For example, compared with the estimated 11.2 million total unauthorized immigrants living in the United States in 2010-a number that reflects the decline that followed the recent recession (Passel and Cohn 2011)—only 580,107 "aliens" were deported by Immigration Customs Enforcement in 2009 (DHS 2010). While immigration enforcement is certainly devastating to those deported individuals and the families they left behind, perhaps the larger power of the enforcement apparatus is not the particular raids or deportations that take place but rather the everpresent potential for a raid that hangs over workers' heads.

The challenge that labor standards enforcement agencies face, therefore, is how to distinguish their mission from that of immigration enforcement agencies in order to reach out to a vulnerable population that is likely to be skeptical of their efforts. Though President Obama has infused resources into the Department of Labor, his employer audits, or "silent raids," have also garnered support among anti-immigrant lobbyists who argue that the president is not doing enough to curb undocumented migration (Krikorian 2011). While seemingly less controversial than the Bush-era policies of border militarization and mass deportations, these raids have in fact reached many more companies and are considered a "far more effective enforcement tool" (J. Preston 2010). They also send a chilling reminder to all workers who labor in the shadows that their place in U.S. society is precarious. ${ }^{7}$ Undocumented workers' vulnerability is further complicated by their usually low levels of education, by language barriers, and by their general lack of familiarity with U.S. legal systems. The availability of formal protections is therefore insufficient to truly protect the rights of all immigrant workers, and the role of institutional intermediaries is particularly important for the undocumented population.

\section{Beyond the Bureaucracy}

Within this context, a complex bureaucratic system has emerged to enforce workplace rights. At the federal level it includes the Department of Labor's Wage and Hour Division and Occupational Safety and Health 